\title{
Ruthenian Devotional Songs As Collectors' Items?
}

\author{
Dieter Stern \\ Ghent University
}

\begin{abstract}
At the turn of the sixteenth and the seventeenth centuries, syllabic devotional songs in Ruthenian (RDS) make their first appearance as occasional appendices or notes in the margins of manuscripts serving quite divergent functions (triodia, evangelia and the like). The first systematic collections of RDS were compiled abroad by Ruthenian monks having left Ukraine for monasteries around Moscow from the 1660s onwards. It required several more decades, till the beginning of the eighteenth century, before these songs were also being systematically collected in song manuscripts throughout the Ruthenian lands themselves. The article argues against established views to the effect that this documentary gap was due to a massive loss of seventeenth-century Ruthenian song manuscripts. It should rather be taken at face value as an indication that some perceptual change with respect to devotional songs is likely to have taken place among Ruthenian literate classes at the beginning of the eighteenth century. It is argued that the rise of Ruthenian song manuscripts marks the beginning of a collecting culture, which treats devotional songs as a cherished and coveted collectable, where heretofore no particular value seems to have been accorded to these songs. The article explores the social profiles of song collectors and the individual makeup of song collections to offer a hypothetical outline of this emerging collecting culture, addressing issues of modes of exchange, methods of collecting and compiling, the specific relationship between collector and collectable, with a view to arguing for a highly individualized and intimate culture between private devotion and incipient object-oriented consumerism.
\end{abstract}

Keywords: Ruthenian devotional songs, chants, collectors, manuscript culture, eighteenth century.

AN ENIGMATIC DOCUMENTARY GAP

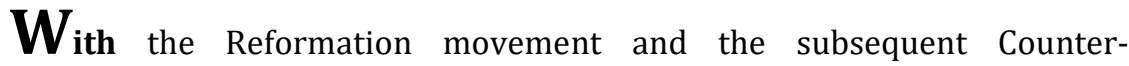
Reformation, new forms of expression were introduced into Ruthenian ${ }^{1}$

\footnotetext{
${ }^{1}$ Ruthenian is used in this paper as a cover term for a class of religious songs and the culture in which they are embedded. Culture, in our understanding, includes language among others, but is certainly not restricted to it. Indeed, one of the basic features of Ruthenian devotional songs (RDS) is their being written in a variant of what is commonly referred to as prosta mova, though as a rule with a somewhat
} 
religious life, spurring and invigorating spiritual individualism beyond the beaten tracks of time-honoured liturgical devotion. Among these, syllabic religious songs, mostly composed to popular Polish and Western dance rhythms (Findeizen 132; Dolskaya-Ackerley; Zosim, Zakhidnoievropeis'ka dukhovna pisnia 54; Zosim, Skhidnoslov"ians'ka dukhovna pisnia 231), were greatly popular with Orthodox and Uniate clerics and laymen alike, to the great annoyance of conservative Orthodox commentators like Ivan Vyshens'kyi, who famously ranted against the stench of Latin songs (Eremin 22). These songs seem to have been around for quite some time by the last quarter of the sixteenth century, before they showed up in written records from 1604 onwards. In striking contrast to their immediate popularity and spread, written records remain few throughout the seventeenth century and are basically restricted to the occasional registration of song texts in the margins of manuscripts of quite different denominations. ${ }^{2}$

As is witnessed by a set of manuscript song collections from the 1680 s90s, which appears to have been compiled by expatriate Ruthenian clerics

stronger Church Slavonic element (Rabus). In fact, some of these songs-especially but not exclusively those which are ascribed to the so-called Nikon School of Poetry (Nikonovskaia shkola, cf. Pozdneev) - tend towards an almost pure Church Slavonic usage. Though Church Slavonic syllabic religious songs of the Nikon School are clearly inspired by RDS, the question may indeed be asked whether these are in fact Ruthenian at all, not only in a linguistic but also in a cultural sense, the more so because only a few of these songs found their way into song collections outside Moscow and its immediate surroundings. The cover term Ruthenian is also suggestive of a literary culture from which RDS originated and where they circulated. It is, however, difficult to pinpoint the regional origin of most specimens of RDS, so in this respect the reference of Ruthenian must of necessity remain vague, referring to all regions where Eastern Slavic was spoken outside of Russia, independently of their eventful history with its oft changing political allegiances. This vague conception is further justified by the ultimate spread of RDS, which indeed covers all Eastern Slavic-speaking regions as defined above, suggesting a cultural unity among them. The only exception to this is the Hetman state, where up to now hardly any RDS manuscripts have been identified. The fact that RDS also spread into Russia and even to the Southern Slavs (especially Austro-Hungarian Serbia) does not contradict this suggestion, because in both Russia and Serbia RDS were clearly perceived as foreign. 2 (1) NBU Mykhailivs'kyi Zolotoverkhyi mon., f. 307, no. 529 (1643), 563r [Uchytel'noe evanhelie, 1604]: (i) Нынъ веселый намъ день насталъ; (2) NBU f. VIII 206m/27, 130v-131r [Latopis lwowski, 1649]: (i) Радуйся, Марїе дпвамъ царице, (ii) О прекрасная пустыни, (iii) О дпво произбранная. (3) NMASh F. 333, 9v ff [Triodion 1660-80]: (i) Аггели сппваютъ, ппснь богу воздаютъ, (iі) Дпвая днесь Христа раждаетъ, (iii) $\bar{W}$ оутробы дпвыя богъ произыйде, (iv) Пастыре в' ночи гды пасли в' темности, (v) Предвпчный родися под лпты, (vi) Христосъ спаситель и вспмъ впрнымъ православнымъ просвптитель. (4) NMASh Q. 219, $65 \mathrm{v}$ [Heirmologion, last quarter of the 17th c.]: (i) Ішрдане рпко оуготовися. 
from Kyiv in monasteries in and around Moscow, there must have been quite a substantial body of Ruthenian devotional songs by that time (Pozdneev; Neumann). Up to this date, experts in the field have wondered why no song collections of this period have been preserved on Ruthenian soil proper, and they have usually come up with the suggestion that these manuscripts must have existed but did not survive into the age of philological rediscovery in the nineteenth century. ${ }^{3}$ It stands to reason that the manuscripts we know of today represent but a small fraction of all manuscript song collections that were ever compiled throughout the seventeenth and eighteenth centuries, but the assumption of a wholesale loss of manuscripts to account for the complete documentary gap at hand would beg a specific explanation. If mere age were the cause for this loss, why would there not be a single manuscript from before the turn of the seventeenth century, and a wealth of them right from the beginning of the eighteenth century? Should manuscript loss due to distance in time not display a more gradual profile? Apart from that, with the appearance of specific manuscript song collections, the practice of writing down songs in the margins of various manuscripts more or less subsides, as if it were either one or the other. Massive loss of manuscript song collections thus seems a problematic if not unlikely scenario. It is therefore possible that the documentation gap neatly reflects the historical situation of the seventeenth century, which means that up to the beginning of the eighteenth century, throughout Ruthenia, devotional songs were memorized rather than collected and written down in special manuscripts. ${ }^{4}$ The manuscript

\footnotetext{
${ }^{3}$ Significant losses of manuscript song collections owing to constant use are assumed by Iavorskii (5). Tichý points to bad storage conditions as the main reason for manuscript losses (8). For similar statements see also Vozniak (326) and Speranskii (134). A specific case is presented by the systematic destruction of Uniate books and manuscripts under Bishop Iosyf Semashko in the 1830s (Pikhura 193, 208; Kostiukovets 23seq.). A significant part of Uniate manuscripts was also destroyed when the University Library of Lviv burned down in 1848 (Pidłypczak-Majerowicz 166). See also Stern ("Dukhovnyi kant" 232). All this accounts for losses as such, which no one would seriously deny, but-with the possible exception of constant use-none of it can account for the observed imbalance of losses. As for constant use, it could explain a situation where there were fewer seventeenth-century than eighteenth-century manuscripts, but it cannot explain the complete absence of seventeenth-century manuscripts.

${ }^{4}$ A primarily oral transmission is also assumed by Dieuwke van der Poel and Cécile de Morrée for the devotional song tradition of the Devotio moderna movement in the Low Countries (375). An oral transmission would, however, not fit in with the general assumption that the creation and propagation of Ruthenian devotional songs was originally linked to poetic classes within the trivium of Basilian and Jesuit seminaries, which implies a priority of the written channel over the oral from the outset
} 
collections of RDS from the end of the seventeenth and the beginning of the eighteenth century thus might possibly not happen to be the earliest remnants of this manuscript genre that have come down to us, but would rather represent the very first specimens of their kind on Ruthenian soil. ${ }^{5}$

These oblique observations are indicative of a perceptual change with respect to devotional songs having taken place sometime around the turn of the seventeenth and eighteenth centuries within Ruthenia, which seems to have turned these same songs from self-evident features of daily spiritual expression into cherished objects in need of preservation in writing. On the face of it, this assumption seems to be confirmed by the appearance of manuscript song collections outside their region of origin among expatriate Ruthenian monks and clerics in Moscow around 1680, which predates the first Ruthenian manuscripts by at least two decades. In the Muscovite context these songs may be assumed to have undergone a revaluation. For the expatriate monks, they may have served as a cherished memory of a lost home; for members of Muscovite noble families, like Prince Cherkasskii's wife, who commissioned and owned one of the Muscovite collections from the 1680s, these songs are likely to have been appreciated as an exotic novelty out of the ordinary (Neumann). The common denominator for both is that the rise of an exclusive manuscript genre for devotional songs is linked to a real and/or perceived change of their social embedding.

What then could have been the perceptual change which gave rise to a different treatment of Ruthenian devotional songs at the beginning of the

(Sidorenko 29; Makhnovets' 1: 435; Kostiukovets 5). Though it is true that very little evidence can be produced to support this specific claim, an original link to the social environs of clerical schools and seminaries cannot be denied for the rise of Ruthenian devotional songs (Stern, Die Liederhandschrift 262-66). So, if there was a written transmission prior to organized song collections, what did it look like apart from notes in the margins? Were they jotted down on loose scraps of paper, then memorized, so that the scraps of paper could be thrown away? Was it throw-away literacy as supportive of, rather than different from, oral transmission? This would account for the chaotic and intractable wealth of variant readings in later Ruthenian song manuscripts in contrast to the closed recensions of the seventeenth-century Moscow group of song collections, which I interpreted earlier in terms of a contrast between a mixed oral-written Ruthenian tradition on the one hand and a purely written Muscovite tradition on the other hand (Stern, "Dukhovnyi kant").

${ }^{5}$ Medvedyk and Rothe (2:76) identify the following RDS collections from the turn of the seventeenth-eighteenth centuries: (i) LNBS Petrushevych 233 (first part dating from the 1690s, the rest is 18th c.), (ii) RGADA f. Osnovnoi 994 (end of seventeenth c.), (iii) LNBS Petrushevych 135 (beginning of eighteenth c.), (iv) LNBS Petrushevych 169 (before 1709). A somewhat earlier precursor from the 1680-90s appears to be a manuscript fragment from Belarus described (alas, insufficiently) by Kostiukovets (85-86). 
eighteenth century? A possible hint is provided by the rubric of each subsection of an early eighteenth -century collection, which was compiled at the Uniate monastery of Suprasl (LRMA F 19-233): ппсни ... из древнихз ппснописцевъ или ппснопойничищъ (собранныл и) (обще) выписанныл. The first things that attract one's attention are the technical terms pesnopisets and pesnopoinichishche. The first is the well-known term for a hymnographer or songwriter. It refers to a person rather than to a book, and perhaps sobrannyia refers to collecting songs by listening to singers who remember them rather than copy them from a book. But then drevnii would hardly be the appropriate term to use for a living person, no matter how old he might be. The verb vypisannyia clearly implies extracting texts from a written source, which would then be referred to by the strange neologism pesnopoinichishche. But what exactly both words (pesnopisets and pesnopoinichishche) refer to is hard to tell. The strange technical language implies that the compiler was at a loss to find the right word for something that seems to have been a quite recent phenomenon, though again drevnii would suggest otherwise. Whatever the material sources the compiler from Suprasl had to deal with, they may not have been as old and time-honoured as the word drevnii suggests. In my view, drevnii is applied here with quite a different meaning and intention. The compiler, it appears, wants to stress his particular respect for something which he remembers and cherishes, possibly from his childhood or adolescence, and which he presumes was there long before he was born and must therefore be an ancient tradition. It appears to be more an expression of appreciation than a statement of fact. ${ }^{6}$ Though with some reservations, I perceive the use of drevnii as an indication of an incipient appreciation of devotional songs as part of a venerable past, which is in need of being preserved. By stating that the sources of the songs are drevnii, the compiler, as it were, offers a justification for devoting his time and energy to honouring this tradition by providing for it a respectable form of documentation within an orderly and neatly written manuscript

\footnotetext{
6 There is an alternative explanation for the use of the label "ancient" for devotional songs and their sources, which has been applied to a Polish printed collection of devotional songs published under the title Pieśni postne starożytne człowiekowi krześcijańskiemu należące (Raków 1607, 1618). The term starożytne is commonly interpreted as a sign that the songs of this collection have long been in use in church and may therefore be assumed to have been approved by common practice and church authorities, whereas newly composed songs would always imply the possibility of dogmatic flaws and require a process of official approbation. This is basically an issue of censorship, which, for one, would be less applicable to manuscript books like the Suprasl collection, and, what is more, would imply a long and approved tradition of singing devotional songs in church, which seems not to have been true of Ruthenian devotional songs at the beginning of the eighteenth century.
} 
anthology. For anything to become a collectable, it must be considered worthy of being collected.

Though the Suprasl compiler appears to be the only one who more or less explicitly expresses his veneration for devotional songs in general, it may be assumed that others thought likewise and that the mere fact of collections of devotional songs becoming more widespread and fashionable around the time of the compilation of the Suprasl songbook is indexical of these songs' being commonly venerated. The documentation gap for Ruthenian song manuscripts of the seventeenth century would accordingly account for the fact that devotional songs had not yet gained the particular esteem of an honourable tradition. The validity of this hypothesis, however, depends on demonstrating that there were not possibly other more mundane and practical issues at hand that stimulated the production of specific collections of devotional songs. This will be looked into by providing an overview of who compiled, acquired, and owned such collections and for what purposes, if any.

\section{SOCIAL PROFILES OF SONG COLLECTORS}

According to Speranskii, who, however, does not specifically refer to song collections but includes manuscript miscellanies of all kinds, the typical manuscript owner in Russia would be recruited from one of the following social groups: "The petty gentry in the capitals and in the provinces, the petty servants, the petty bourgeoisie, the merchant class, the lower clergy, and the literate peasantry" (86). ${ }^{7}$ For the Ruthenian territories, Ivchenko and Krekoten' provide a similar general list, specifically encompassing song manuscripts, devotional and secular alike: 8 "the lower clergy, pupils of fraternal schools, students of colleges and academies, merchants, craftsmen, and even villagers" (6). ${ }^{9}$ Both statements differ as to the social strata figuring most prominently among the owners, suggesting a more clerical Ruthenian against a more secular Russian profile (Stern, Die Liederhandschrift 268). Whereas Speranskii backs up his observation by providing source data from 76 privately owned manuscripts, among which figure just two collections of devotional songs, Ivchenko and Krekoten' do not provide any material

\footnotetext{
7 All translations are my own. "мелкопоместное дворянство в столицах и в провинции, мелкий служилый люд, мещанство, купечество, низшее духовенство и грамотное крестьянство."

${ }^{8}$ For a statement about Russian owners of song collections, see Peretts (305) and Livanova (1: 463).

9 “нижчі клірики, учні братських шкіл, студенти колегій і академії, купці, ремисники, і навіть селяни".
} 
evidence. For the present paper, it therefore proved essential to devise a list which would correlate social-professional domains and groups with regional affiliation as well as ownership status and patterns of content. In this list I have listed "Church" and "Education" as separate socio-professional environments, though both were closely interconnected at the time in question. There was no secular system of state education of any size, and both church services and education were more often than not intertwined at a personal level. This is tellingly demonstrated by the job description of diakuchytel'-which is, by the way, exclusively found in Ruthenian manuscripts. Keeping both domains apart, notwithstanding their interrelationship, appears, however, to be justified by the putative serviceability of devotional songs in both professional domains. Devotional songs could acquire professional relevance within the church proper as paraliturgical elements accompanying liturgical celebrations, whereas their professional relevance in the context of teaching is less obvious. ${ }^{10}$

The table draws on data from Stern (Die Liederhandschrift), Medvedyk and Rothe, and Žeňuch (Kyrillische paraliturgische Lieder). The sociogeographical setting captures in a necessarily simplified manner the basic contrast of city versus countryside. Monasteries as well as military contexts have been excepted from this gross basic division, since both constitute closed social environments of their own, quite independent of their actual location in either city or countryside. The regional labels have been narrowed to just two: RUTH for Ruthenian territories and ROSS for territories within the confines of the Russian Empire, the latter also including the Right Bank part of Ukraine (the Hetmanate), which on closer inspection displayed the same distributional patterns as the Russian territories proper. RUTH identifies those areas which either belonged to the Polish-Lithuanian Commonwealth prior to the Polish partitions, or which were part of the Austro-Hungarian Empire at the time when the manuscript in question was either compiled or changed ownership. Ownership status pertains to persons mentioned in the marginal notes as either compiler or owner. Both can, of course, be combined. No distinction is made between designing a new collection or simply copying it over from an already existing collection. The contents differentiate between devotional songs, which form the focus of our interest, and secular songs. Secular songs can be either panegyrical (e.g., praise of the Russian emperor) or lyrical (love songs). This latter category is not taken into consideration.

\footnotetext{
10 In cases where the total number per professional group is higher than the total for either ownership status or the contents of the respective professional group, the difference is due to the ownership status or contents not being known for all manuscripts according to the respective professional group.
} 


\begin{tabular}{|c|c|c|c|c|c|c|c|c|c|}
\hline \multirow{3}{*}{$\begin{array}{l}\begin{array}{l}\text { Professional } \\
\text { domain }\end{array} \\
\text { Professions }\end{array}$} & \multicolumn{4}{|c|}{$\begin{array}{l}\text { Regional affiliation \& } \\
\text { socio-geographical setting }\end{array}$} & \multicolumn{3}{|c|}{ Ownership status } & \multicolumn{2}{|l|}{ Contents } \\
\hline & RUTH & RUTH & ROSS & ROSS & \multirow[t]{2}{*}{ compiler } & \multirow{2}{*}{$\begin{array}{l}\text { compiler- } \\
\text { owner }\end{array}$} & \multirow[t]{2}{*}{ owner } & \multirow[t]{2}{*}{ devotional } & \multirow{2}{*}{$\begin{array}{l}\text { devotional } \\
\text { secular }\end{array}$} \\
\hline & coun. & city & coun. & city & & & & & \\
\hline \multicolumn{10}{|l|}{ CHURCH: 45} \\
\hline $\begin{array}{l}\text { monks, nuns: } \\
6\end{array}$ & \multicolumn{2}{|l|}{3} & \multicolumn{2}{|l|}{3} & 5 & 1 & 0 & 3 & 2 \\
\hline bishops: 1 & 0 & 1 & 0 & 0 & 0 & 0 & 1 & $?$ & $?$ \\
\hline priests: 12 & 7 & 1 & 1 & 3 & 4 & 1 & 7 & 7 & 4 \\
\hline cantors: 21 & 16 & 1 & 4 & 0 & 5 & 0 & 15 & 9 & 6 \\
\hline $\begin{array}{l}\text { cantor- } \\
\text { teacher: } 7\end{array}$ & 7 & 0 & 0 & 0 & 5 & 0 & 2 & 6 & 0 \\
\hline sextons: 2 & 2 & 0 & 0 & 0 & 1 & 1 & 0 & 1 & 1 \\
\hline \multicolumn{10}{|c|}{ EDUCATION: 19} \\
\hline teacher: 8 & 7 & 0 & 0 & 1 & 2 & 2 & 4 & 4 & 3 \\
\hline $\begin{array}{l}\text { priest's son: } \\
7\end{array}$ & 7 & 0 & 0 & 0 & 5 & 2 & 0 & 2 & 3 \\
\hline $\begin{array}{l}\text { student of } \\
\text { theology: } 1\end{array}$ & 0 & 0 & 0 & 1 & 0 & 1 & 0 & 0 & 1 \\
\hline pupils: 6 & \multicolumn{2}{|l|}{4} & \multicolumn{2}{|l|}{2} & 2 & 2 & 2 & 3 & 2 \\
\hline \multicolumn{10}{|c|}{ CLERKS \& MINOR FUNCTIONARIES: 10} \\
\hline $\begin{array}{l}\text { public } \\
\text { notary: } 1\end{array}$ & 0 & 0 & 0 & 1 & 0 & 0 & 1 & $?$ & $?$ \\
\hline clerks: 3 & 0 & 0 & 0 & 3 & 3 & 0 & 0 & 3 & 0 \\
\hline scriveners: 4 & 0 & 0 & 0 & 4 & 1 & 0 & 3 & 1 & 4 \\
\hline townsmen: 2 & 0 & 1 & 0 & 1 & 0 & 0 & 2 & $?$ & 1 \\
\hline \multicolumn{10}{|c|}{ MERCHANTS: 6} \\
\hline merchants: 6 & 0 & 0 & 0 & 6 & 0 & 0 & 6 & 1 & 1 \\
\hline \multicolumn{10}{|l|}{ MILITARY: 3} \\
\hline Cossack: 1 & \multicolumn{2}{|l|}{0} & \multicolumn{2}{|l|}{1} & 0 & 1 & 0 & 0 & 1 \\
\hline officers: 2 & 0 & & 2 & & 2 & 0 & 0 & 1 & 1 \\
\hline \multicolumn{10}{|l|}{ ARTISANS: 1} \\
\hline smith & 1 & 0 & 0 & 0 & 0 & 0 & 1 & 1 & 0 \\
\hline \multicolumn{10}{|c|}{ PEASANTRY: 1} \\
\hline peasant & 1 & 0 & 0 & 0 & 1 & 0 & 0 & $?$ & $?$ \\
\hline \multirow[t]{2}{*}{$\begin{array}{l}\text { Sum total: } \\
85\end{array}$} & $\begin{array}{l}44 \\
(5) \\
\end{array}$ & 3 & $7(6)$ & 20 & & & & & \\
\hline & \multicolumn{2}{|c|}{ RUTH: 52} & \multicolumn{2}{|c|}{ ROSS: 33} & & & & & \\
\hline
\end{tabular}

The most obvious finding to be drawn from the table is a wholesale confirmation of the divergent professional class distribution profiles for Russia and the Ruthenian territories. For Russia, there are more secular urban professionals; in Ruthenia, however, there are more country parishioners who appear as manuscript compilers and owners. The common denominator between both groups has been pointed out by Peretts, who identified both as literate classes from which the intelligentsia or educated, meritocratic classes of later periods would emerge (298). As Bourdieu pointed out, it is this socially upward-oriented lower middle class which 
enthusiastically embraced scholarly pursuits and had a taste for activities like collecting, which required a significant commitment of time (549-50).

Though this observation provides for a plausible overall sociological framework, it leaves, however, the distributional gaps in both regions unaccounted for. Why would neither Ruthenian secular urban professionals nor parish priests in the Russian countryside, as members of the literate classes, display the same taste for Ruthenian devotional songs? To begin with, Ruthenian devotional songs within the Polish-Lithuanian Commonwealth not only derived from a rapidly growing culture of Polish devotional songs, but they may be assumed to have been embedded into this Polish song culture owing to a weakening dividing line between the Polish and the Ruthenian cultural spheres. The emergence of Ruthenian devotional songs thus came about quite naturally among Ruthenians. Though they were eyed with some reserve by prominent individual Orthodox Ruthenians like Vyshens'kyi in the beginning, the general feeling that these songs were somehow culturally foreign elements seems never to have been particularly strong, whereas in Muscovite Russia there was a sharp consciousness of the foreign Western origins of these same songs. This is neatly reflected in the terminology used in the titles of and rubrics within song manuscripts. Whereas Ruthenian devotional songs were consistently and in all cases covered by the simple and neutral term pesni, song manuscripts from Russia identify them more often than not either as psal'my for devotional songs or as kanty for devotional as well as secular, mostly panegyric songs. Both terms clearly refer to the foreign origin of the songs, psal'my, by using the soft Polish $l$ instead of the velar $l$ of the Russian Church-Slavonic psalmy (meaning, of course, the psalms), and kanty, by its Latin etymology (cantus), but more so possibly by its specific reference to the new and refined form of singing in three voices, ${ }^{11}$ the so-called partes, brought to Moscow from Kyiv and being basically restricted to select centres of monastic learning and initially to the court culture (Dolskaya-Ackerley; Plotnikova). This makes for a basic contrast between what is considered ordinary in Ruthenia and uncommon and outlandish in Muscovite Russia.

The specific aspect of the perception of RDS together with their Polish counterparts as something exotic in the environs of Moscow is confirmed by a number of observations, made by Jensen (62-63). The Dutch ambassador in Moscow, Coenraad van Klenck (1628-91), noted that among the upperclass of Muscovy there were many music lovers who would employ Polish musicians. This observation neatly accounts for the many Polish songs in Cyrillic transliterations found in collections of devotional songs from the 1670 s to the 1690 s, most notably Petr Skrzolotowicz's short collection of

${ }^{11}$ In medieval and early modern Latin hymnody, cantus refers to the main voice of polyphonic chant. 
Polish songs in Cyrillic from 1676 (Rothe). It also fits with Simeon Polotskii's complaint in his foreword to his Rifmotvornaia psaltyr' (Rhymed Psalter) that many in Moscow much appreciated the singing of Polish songs without understanding them. An early aficionado of Polish and Ruthenian spiritual songs appears to have been Avdot'ia Ivanovna Pronskaia, Prince Cherkasskii's wife, who between 1675 and 1686 commissioned and owned one of the earliest collections of spiritual songs from Moscow, RNB Pogogin 426 (Neumann 85). Polish and Ruthenian devotional songs may have been brought to Moscow by Kyivan monks, but they very soon became much appreciated as collectables by the secular classes. It is probable that already at this early point the more urban and secular patterns of RDS distribution were determined in Imperial Russia.

The spread among the Ruthenian clerical professions was certainly helped a lot by the spread of the Church Union, although Ruthenian Orthodox clerics were by no means averse to Polish-style poetry, either read or sung, as the literary production of the most prominent Orthodox centre of learning, the Mohyla Academy, with its many edited volumes of virshy, unequivocally shows. When devotional songs were introduced to monasteries around Moscow, probably from the 1660s onwards, we may assume that they were met with the same vigorous repudiation as the more prominent innovations entering Muscovite clerical life in the wake of Patriarch Nikon's reforms. Though the Moscow group of song collections dating from the $1680 \mathrm{~s}-90$ s would appear to testify to the contrary, strong feelings of Orthodox cultural resentment may be assumed to have prevailed and effectively blocked the spread of Ruthenian devotional songs with their frivolous dance rhythms beyond the fairly constricted sphere of the Muscovite court and monasteries into Russian country parishes. Efforts to set up a specifically Orthodox style of devotional songs point in this direction. The deacon-monk Damaskin, who compiled the Moscow song manuscript GIM 1743, took great pains to alter the lexical makeup of many songs by substituting Church Slavonic for Ruthenian items, and the acrostic song poet, German of the New Jerusalem Monastery, went out of his way to compose complex songs in a very heavy and austere style, which, however, never spread beyond Moscow or into the eighteenth century. The assumption that Orthodox conservatism overcame Ruthenian liberality, should, however, be taken with a grain of salt, as it was the most conservative faction of Russian Orthodoxy, the Old Believers, who regularly included Ruthenian devotional songs in their manuscript miscellanies and took them into the remotest backwoods of Russia (Filosofova).

Thus, Muscovite Russian Orthodox cultural conservatism combined with the earmarking of devotional songs as a foreign import within Russia is likely to have contained their further spread. The inherent Uniate tendency to blur the boundaries between the Roman and Byzantine rites may have 
additionally supported the spread of devotional songs among clerical professions. But if Ruthenian devotional songs became so extremely popular in the Ruthenian countryside, why did they not leave any traces among the city dwellers of the Polish-Lithuanian Commonwealth? Urbanization went together with cultural Polonization, and the middle classes of Ruthenian cities may be expected to have by and large adopted Polish language and culture. Thus, it is not unlikely to assume that the representatives of the literate middle classes of Vilnius (Wilna) or Lviv would prefer buying or copying a printed Polish language songbook over collecting Ruthenian songs. The mere fact that Polish devotional song collections were printed quite regularly at the printing shop of the Jesuit Academy at Vilnius throughout the eighteenth century ${ }^{12}$ fits this assumption. ${ }^{13}$ Alluring as the

12 Up to now no complete list of printed collections of Polish devotional songs from Vilnius (Wilna) has ever been compiled. I was able to identify three such editions, but there may yet have been others: (1) Rotuły Abo Piesni Adwentowe Zebrane, w Wilnie w Drukarni Akad. Soc. Jesu. Roku P. 1721; (2) Pieśni nabożne na święta uroczyste ..., w Wilnie w Drukarni Akad. Soc. Jesu. Roku Pańskiego 1745; (3) Piesni nabożne według porządku dorocznego ..., w Wilnie w Drukarni Akad. Soc. Jesu. Roku Pańskiego 1761.

${ }^{13}$ As one reviewer suggested, there may, of course, have been various reasons why any corresponding Cyrillic printed book collections of RDS never made their appearance alongside the Polish ones at Vilnius (Wilna) or Lviv, such as attitudes toward the printing of books in the prosta mova or the financial state of Cyrillic printing shops, but these assumptions, rather than disproving our hypothesis, confirm it, if shown to be true. Would not a negative attitude toward printed books in prosta mova amongst the Ruthenian citizens of either Vilnius or Lviv be inspired by their having adopted the more prestigious model of Polish culture? And would not the bad financial state of Cyrillic printing shops be a consequence of a general neglect of Ruthenian literary culture by a citizenry that had opted for Polish? Invoking a scenario of cultural suppression by referring to the colonial status of the Orthodox and Greek Catholic faithful in Crown Poland glosses over the fact that Polish cultural colonialism was not based on restrictive measures and prohibition, but on a selfconscious attitude of supremacy, which fostered the rejection of one's cultural heritage among Ruthenian citizens. There is probably no way of ever determining for sure what drove linguistic choices in multilingual cities like Vilnius or Lviv, but there is no doubt that Polish was the binding element and the cultural model for most citizens, as has been aptly expressed, in the case of Vilnius, by Frick: "The picture of strict separation and maintenance of difference was a dream of the various clergies and of late modern nationalisms; such distinctions were largely ignored in the daily life of early modern Wilno.... We hear people communicating with each other across linguistic and ethnic boundaries .... But mostly we will hear them all speaking Polish ... as this was the language of public discourse in most circumstances" (116). If we again take the perspective of the printer and his reading customers, a book in Polish would reach anyone interested in religious songs in Vilnius, whereas a similar book 
notion of a largely Polonized citizenship may be to account for the overall lack of urban song collectors in the Ruthenian cities, it must, however, not be forgotten that it was in these very cities that the way was paved for private, non-professional interest in religious singing and songs among the parishioners of the Brotherhood churches of Lviv and the Uniate Church of the Holy Trinity at Vilnius, which admitted parish members to partake in church chant (Kuz'mins'kyi and Kapral' 104). Moreover, at these places the traditional monodic chant of the irmologion was early on supplemented by rhythmic and often polyphonous singing in the fashionable Western style of the cantus fractus, through which it may be supposed that RDS may have been introduced into the church services for the very first time (Kuz'mins'kyi and Kapral' 102).

\section{Between Pastime and Status: Collecting Songs or OWNing Them?}

The vast majority of ownership marks are unspecific in the sense that they do not allow for any definite conclusions about the specific role of the person(s) indicated and the processes of compilation and transaction of collections. Anyone indicated as owner may have in fact also been the original compiler of the manuscript, unless there is an indication to the contrary, such as an additional note of compilership identifying a different person as the original compiler, or a note identifying the owner also as the buyer of the manuscript in question. By and large, however, none of the ownership and transaction marks allow for any specific conclusions as to whether collections of devotional songs were commissioned and traded rather than compiled as a private pastime of sorts. Knowledge of this, however, is a prerequisite for determining with any degree of certainty the way the possession of a song collection was interpreted and perceived. What would be the possible social cachet of being able to boast of the possession of a collection of devotional songs? Would owning a song collection be valued as proof of relentless labour and allow the owner to show off how truly committed he or she was to the objects being collected? Would the standard social expectation thus be that the owner and compiler would be the same person? This would, in any case, be in line with Bourdieu's interpretation of collecting as a behaviour of the rising middle classes through which they staged the distinctive meritocratic value of commitment to a given task (549-50).

The few ownership marks that register a financial transaction, if they are not right away discounted as mere exceptions, would suggest otherwise. But

in Ruthenian would probably reach only a subsection of the ranks of song lovers. The market conditions directly reflect on consumers' tastes and choices. 
still the acquisition of complete collections, as in these few attested cases, could also be interpreted as forming part of a more complex and diversified compiling process, in which whole collections were acquired alongside individual songs, to be recombined into a new collection of one's own composition and design. This would be basically, what many modern stamp collectors do.

If we, however, assume that the preferred pattern would have been to buy or even commission song collections, a different interpretative pattern of ownership is likely to have prevailed among owners of song collections. One obvious interpretation would be that owning a song collection as such was considered a sign of the social respectability (rather than real status) of the owner. Iakov Dobrynin's 1799 publication of a ready-made collection of devotional and panegyrical songs in print could thus be seen to relieve the Russian middle classes of the pains of having to compile or try to obtain a handwritten collection of devotional songs in order to meet middle class expectations. Of course, both interpretations, with their concomitant motivation for either compiling or acquiring a devotional song collection, may well have co-existed in the same population.

Relying on the testimony of the song manuscripts themselves, little points to a divide between the social groups that typically compiled or acquired them, with the exception of merchants in eighteenth-century Russia, all of whom bought their collections rather than compiled them. There is, however, no corresponding social group which stands out exclusively as compilers. ${ }^{14}$ This not being the case, there is no clear indication within the manuscripts themselves that there was a true market, with an associated production chain from producer to consumer, for song collections as ready-made commodity items.

An admittedly late report from the beginning of the twentieth century, however, attests to just this sort of professionalized supply chain, identifying so-called chornoknyzhnyky 'magicians' as professional agents of the reproduction and dissemination of song collections:

It was then a common practice that at the priests' homes one would often find these "black magicians"-i.e., vagrant scribes (usually monks)copying books for an agreed-upon fee. Occasionally, such a scribe would come to a village in winter and villagers would hire him to come to their hut for the entire duration of the stay, and he would write and write until he

\footnotetext{
14 Notwithstanding Findeizen's somewhat enthusiastic surmise that with respect to 18th-century Russia "there is no doubt that among the skillful copyists in church circles, especially among the sovereign and patriarchal singers, there were experienced specialists who compiled similar collections to order or even prepared them in advance for future sales," there is very little evidence indeed of priests and monks serving this function and providing for professional supply networks (II, 133).
} 
had finished copying the book he carried with him. They gave him food, paid him with eggs, sausages, and through the winter, from the goose pen of these black scribes came out books of church chant, Bohohlasnyky, collections of sermons and teachings, letters of heaven, ancient legends about the Macedonian king Alexander, about Solomon, etc. These manuscripts served as the first mode of instruction for the young, for children learned to read from them. (Stryps'kyi 7; Medvedyk, "Rukopysnyi zbirnyk" 103) ${ }^{15}$

Medvedyk identifies Ivan Iuhasevych as well as Ivan and Mykhailo Levyts'kyi as professional songbook compilers, who are indeed known for having authored several songbooks ("Rukopysnyi zbirnyk" 103-04). ${ }^{16}$ Stryps'kyi's report implies that this was a fairly common practice at the time-which appears not to be his own time-and in the Transcarpathian region. So, acquiring and owning rather than compiling song collections may be assumed to have contributed significantly to the dissemination of devotional songs. Still, the highly individual composition of almost all extant manuscript collections is suggestive of solitary individual collecting activities playing a significant role alongside the professionalized reproduction depicted by Stryps'kyi. As a matter of fact, if this kind of reproduction were predominant, there should be a sizable proportion of exactly matching copies among the extant manuscript collections of Ruthenian devotional songs, even if we allow for the commissioner to have had an active part in the selection of the material to be copied. With the exception of Iuhasevych's collections, there are, however, hardly any song collections with a more or less identical repertoire in roughly identical order. On the other hand, it is difficult to

15 “Тогды такій звычай быв, што при священниках найчастьйше переписували сесь чорнокнижники,-то есть вандровані писарђ (звычайно черцђ)一за уговорену платню. Бывало приходить зимою такій писар у село, селяне наймали его до своеъ хижи на цълое удержанье, а он став писати, та писав, писав, доки не переписав ношену с собою книгу. Давали ему ьдъня, платили яйцями, ковбасами та через зиму працюючи, повыходили из под гусячого пера тых чорнокнижников співаники церковні, Богогласники, зборники проповідей та поучень, листы небесні, стародавні оповідання за царя македонського Александра, за Соломона и т. д. Сесь рукописні книги служили першою наукою для молодых, бо дьти училися на них читати."

16 Vodoff suggests the possibility that the scriveners indicated in Russian song collections (Peretts 300 and 302, no. 14, 15 and 31) might be professional compilers of song and other anthologies, but then he admits that the professional label kopeist is rather to be taken as the status identification of a lower order official (362). I would guess that professional labels added to compilers' or owners' names are rather meant to identify the person in question in terms of his social position. Like the names they are added to, these labels are about who one is, rather than what one does to add to one's income. This implies that copying songbooks was not a socially accepted profession to which a status label could be linked. 
imagine how largely immobile village dwellers could compile substantial song collections all by themselves, something which obviously requires moving about and going to different places. A highly mobile group, like the chornoknyzhnyky, therefore, should be considered an indispensable infrastructural element to allow for any form of private collecting efforts to be successful. The possibility should therefore be allowed that itinerant scriveners not only delivered wholesale copies of books but also added songs piecewise to already existing collections on demand for genuine and committed collectors.

Up to this point we addressed the chornoknyzhnyky as a professional class in its own right, thereby suggesting a principal divide between compilers and owners as sellers and consumers. By pointing out that many chornoknyzhnyky used to be monks, ${ }^{17}$ Stryps'kyi already provides a hint that the chornoknyzhnyky did not constitute a professional group as such, but that copying books was rather an occasional occupation adding to their income rather than forming its base. Thus, any private song collector who happened to be abroad for an extended period of time could turn into a chornoknyzhnyk, while, being at home, he could just as likely assume the role of a customer of a chornoknyzhnyk, thus blurring the dividing line between professional activity and private occupation.

With a view to the fact that the typical owner of a song collection would be a member of the literate classes, which in the Ruthenian countryside would consist basically of priests and cantors/teachers, it becomes apparent that the role of Stryps'kyi's ominous chornoknyzhnyky must not be overrated. Cantors and teachers in particular constituted a highly mobile professional group, who would not have had to rely on itinerant copyists to compile their private song collections. Cantors and school teachers almost exclusively came from the group famously known as the itinerant cantors (mandrivni diaky, also bursaky or spudei), who, having acquired some basic training at seminaries or theological colleges, would leave these institutions during vacations in the hope of finding employment at a parish school or church. Most of them did not ever intend to resume their college studies and would readily seize upon an opportunity for permanent employment, whereas others would wander from parish to parish for a time, before they settled down. Only a select few would spend their lives in a permanently peripatetic state, such as Kuz'ma Poradyn, whom not even marriage and the begetting of children could keep from wandering about (Martynenko 29596). It may be assumed that Stryps'kyi's chornoknyzhnyky were in fact

\footnotetext{
17 Medvedyk ("Rukopysnyi zbirnyk" 105) raises doubts whether the typical semiprofessional compiler would in fact be a monk, especially in view of the fact that only two song manuscripts can be linked to a monastic setting (Suprasl monastery, LRMA F 19-233; Pistyn monastery, IL f. Franka 4732).
} 
mandrivni diaky, who happened to stop over at one place or another and copied books on request in their search for a fixed appointment somewhere else. Ultimately, it appears that many, if not most, Ruthenian song collectors would not have had to rely on any mobile infrastructure to help them procure songs, but that they themselves created the required long-distance network ties through their own particular way of living. ${ }^{18}$

The fact that merchants stand out as typical second-hand acquirers rather than original compilers seems to provide a clue that it was, after all, only the well-to-do who could afford to buy complete manuscripts, but then a similar number of second-hand buyers can be found among other social groups, such as priests, cantors, teachers, clerks, and scriveners, who may not count as particularly affluent. Thus, financial considerations are not likely to have prevented people from just buying instead of painstakingly compiling song collections. Finally, the fact that only 11 out of the 85 manuscripts analyzed for this paper bear witness to ever having been resold later on, may be taken as an indication that buying whole song collections was not very common after all. ${ }^{19}$

18 Zhitetskii (193) and later Vozniak (334) suggested that song collections were compiled by mandrivni diaky in order for them to be able to earn their livelihood. Both, like so many others after them, took it for granted that seminarians would spend most of their lifetimes as itinerant minstrels, who had to rely on singing devotional songs for paying customers along their migratory routes as the main if not only source of income. The imagery of the singing diak may have been inspired by the oft invoked parallels between the mandrivni diaky and the vagantes or goliards of the Western European Middle Ages. A tendency to romanticize their way of life-most prominently in Nikolai Gogol' (Mylkola Hohol')'s short story Vii-may finally have added to the tendency to overrate the migratory element of the average life cycle of a seminarian. In a more sober appraisal of the typical career of a mandrivnyi diak, such as that of Martynenko, there is likely to be much less space devoted to singing and the associated song collections as an indispensable component of professional equipment.

${ }^{19}$ As a matter of fact, in hardly any manuscript is there any explicit mention made of a financial transaction, such as in RNB Pogodin 426 (Neumann 84-85) and in RNB Q XIV 141 (Peretts 300, no. 15). A manuscript sale is in eight cases deducible from the manuscript's containing more than one ownership mark. Changes in ownership usually occur between strangers bearing different names and often also pertaining to different professions, which by itself would imply some kind of monetary transaction (rather than bequeathing a song manuscript as part of a legacy): NKP XVII L 15 (cantor > cantor-teacher), MGU 1.s.b. 153 (cantor > priest's son), RNB Pogodin 426 (noblewoman > ... > merchant), RGB Undol'skii 900 (nun > clerk), RGB Undol'skii 900 (deacon-monk > merchant), TM 152 (parish priest > cantor), RNB Q XIV 141 (scrivener $>$ scrivener $>$ merchant), RNB Q VII 212 (deacon $>$ cantor $>$ clerk $>$ clerk). In the remaining six cases, the original ownership cannot be ascertained with 
The MATERIAlity of SongS: How Did Collectors Go ABOUT Compiling Their Song TREASURIES?

Though we will possibly never be able to determine if collecting songs was ever perceived of as a goal in itself, it is evident that most song collections represent the fruit of the labour of years of collecting. This is clearly made evident by the highly individual profile of any song collection. There is in fact no song collection like any other, with perhaps the exception of some of the Moscow group of song manuscripts as well as the collections compiled by Iuhasevych. Songs appear to have been chosen on an individual basis, depending on the opportunities for getting hold of new songs, but likewise also according to individual choices, which were possibly meant to attest to the personal taste of the compiler. In accordance with this surmise, it can be demonstrated for quite a few manuscripts that their repertoire represents several layers of additions and completions (sometimes in the form of added leaflets; cf. F 19-233). Other manuscripts, like the Ivanovce miscellany (NKP XVII L 10, dat. 1863) or the Prešov song collection (NKP XVII L 18, dat. second half of the 18th c.), were written by several hands, which may point to a practice of the manuscript owner's letting acquaintances or professionals (chornoknyzhnyky), who happened to know some new songs, write these down by themselves. ${ }^{20}$ Other less durable techniques of acquiring primary source material for a collection may have been leaflets with single songs held together in a box or folder (Petty). Sometimes base

certainty, but an ownership mark being dated much later than the presumed original composition of the manuscript implies a change of ownership, which, with a lesser degree of certainty, is likely to have involved a sales transaction: NKP XVII L 18 (dated mid-eighteenth century, new owner 1808), RGB Muzeinoe sobranie 1676 (compiled 1780, new owner 1804), TM 156 (dated mid-eighteenth century, new owner 1780). It should, however, be noted that a change of ownership, even if it is explicitly marked by verbal descriptors such as продалъ, проданъ, does not necessarily imply any kind of payment, as the following note of donation from RNB Q XIV 128 tellingly demonstrates: "These psalms by Afanasii Gavrilov, a student of the seminary at Novogorod, were sold to him free of charge out of love, to be owned and not to be sold to anyone, and if he sells them, I will take money from him . . 1768 . .." ("Сии псальмы новагородцкой семинариі ученика Афанасия Гаврилова проданы ему бъзденежно і бъзплатно для любови, і владьть ему, никому нъ продавать, а ежели продастъ, то я с него деньги возьму ... 1768 ...") (Peretts 299, no. 5).

20 Not unlike Western European autograph books, which were popular among university students from the fifteenth to the nineteenth centuries and beyond. Autograph books would usually be filled with poems, epigrams and other short texts in the hand of friends and acquaintances one made at university or school (Petty). In fact, Iavorskii speculates about the Prešov collection's having been owned by a student at Kyiv who let his friends and co-disciples enter songs they happened to know into his songbook. See also Vodoff (363). 
collections are further extended by a later owner by simply adding quires containing his own collection. Especially those folder-type collections of loose folia, but also random collections in book form, like the pocket-size manuscript collection LRMA F 19-234, could have served later on to arrange and, as it were, eternalize these personal song treasuries in a neat calligraphic handwriting into a respectable looking volume, which would at once do honour to the treasured songs and add to the pride of their collector. Song collectors would thus be able to enjoy the double pleasure of hunting for the sought-after songs and entering into a more intimate relation with them by sorting and arranging them and finally copying them into the final manuscript, which by itself could subsequently turn into an attractive collectable, as is made evident by individuals acquiring whole song manuscripts. Collecting songs meant searching, identifying, selecting, copying, rearranging, and rewriting them. The very collecting process as such turns songs from (almost) immaterial, ephemeral phenomena into a kind of palpable material object, which allows the collector to enter into an intimate relationship with a highly prized part of his personal reality.

Collecting as a lived experience is also about never achieving completion, though, paradoxically, a predefined closed and finite set of individual collectible items is a prerequisite for collecting, which serves as a standard against which to compare one's personal collecting successes. Since collecting is conceived of by collectors as a personal achievement, collecting cultures are likely to break down where the goal of completion is made available to practically anyone in ready-made collections aiming at completeness. Thus, the 1790 print anthology of Ruthenian devotional songs published at the monastery of Pochaiv under the title of Bohohlasnyk ${ }^{21}$ had, indeed, a sweeping effect on manuscript production. Collecting activity almost ground to a halt, except for the Transcarpathian region, where manuscript collections continued to be compiled well up to the end of the nineteenth century (Vodoff 360; Stern, Die Liederhandschrift 188). Those manuscript collections, which were still being compiled after 1790, often offered nothing but exact copies of the whole or parts of the Bohohlasnyk.

At first glance, this looks like the pre-Bohohlasnyk collecting activity had been born out of need, which was finally being filled by the ready-made print

\footnotetext{
${ }^{21}$ Bogo-glas-nik originally refers to a person (-nik), who speaks with the voice (-glas) of God (bogo-), but -nik may also refer to a book. In Church Slavonic, a bogoglasnik would originally mean a preacher or a book used by a preacher, i.e., a collection of sermons. The editors of the 1791 Bogoglasnik (Ukr. Bohohlasnyk), however, obviously intended a play on words based on the double meaning of Church Slavonic glas as simply "human voice" on the one hand, but then also as "part or voice (of a musical score)" on the other hand, insinuating that theirs is a song book rather than a book of sermons.
} 
compilation, and was therefore never really a goal in itself. But the publication of the Bohohlasnyk had yet another effect. Not only was collecting activity diminished, but also the connected activity of composing new songs came to a sudden stop. It almost looks as if the publication of the Bohohlasnyk, probably against the original intentions of its publishers, had taken the life out of the Ruthenian devotional song culture by undermining the conditions of its dynamic vitality. It is true that devotional songs remained a cherished element of popular culture, but their role and position within that culture had undergone a radical change.

Devotional Songs AND Song Collections: Private Collectables oR PROFESSIONAL TOOLS?

Up to this point we have built up an argument that depicts the extant collections of devotional songs as the manifestation of an incipient collecting culture, conceived of in terms of an intimate activity fitting within the framework of an emergent overall culture of modern individualism. There is, however, possibly also something to be said for a more practical accounting for the sudden appearance of manuscript song collections at the beginning of the eighteenth century. In view of the fact that the clerical professions (priest, cantor) hold a major share among the compilers and owners of song manuscripts in the Ruthenian lands, it could be argued that the spread of manuscript collections was brought about by a shift in liturgical practice which made devotional songs part of the church services within Uniate and possibly also Orthodox Ruthenian parishes (Vodoff 364). Though there are no direct testimonials in favour of this, some parish priests seem to have started to use devotional songs in church as early as the first half of the eighteenth century. ${ }^{22}$ A song collection owned by a cantor or

22 The overall structure and makeup of the so-called Bohohlasnyk of Kamiane (IL f. Franka 3/4784), dating from 1734, is highly indicative of this particular manuscript's having been compiled and used specifically for church services (Zatyliuk 271-72). Within a thematic base structure, it applies a strict order according to the liturgical year and offers a choice of songs for all major feast days. The systematicity of the collection becomes particularly apparent with regard to the selection of saints' songs. The compiler obviously went out of his way to leave no gaps and to have at least one song for every saint, who would be marked by the Orthodox calendar as a major figure of veneration, where most other song collections would not provide more than a random selection of songs for the most popular saints, like St. Nicholas of Myra, and a few odd songs for lesser-known saints. With its somewhat inappropriately chosen genre label, Кнъга ппсноппнйй сирпчъ їрмологїонъ (Воок of Hyтns, i.e., Heirmologion), the Suprasl collection (LRMA F 19-233, dat.1730s-40s) seems also to 
priest would then appear to be nothing but part of his professional equipment. The overall makeup and structure of most manuscript collections suggests, however, otherwise. Most of them, even those few with a neat structure according to the liturgical year or according to larger thematic units (typically Lord's songs followed by songs in praise of the Virgin Mary followed by Saints' songs), could hardly meet the requirements of a regular church service due to their random and largely deficient choice of feast days and saints. What is more, most collections of devotional songs lack musical scores, which does not recommend them as particularly useful tools for professional singers. Not even the much simpler and economical technique of indicating melody references (podobni), pointing out better known songs as musical models, was widely employed in these collections. When dealing in particular with Ruthenian devotional song collections, one cannot avoid the impression that the songs were never meant to be sung. ${ }^{23}$

But then professional needs and private pastime need not necessarily be mutually exclusive. After all, it was not by any kind of official decree that first Uniate Basilian monks, and then parish priests and cantors, made the moves to introduce devotional songs into the church. It appears to have been an insidious development based on private initiative, which even ran counter to official decrees and injunctions to the effect that the Byzantine rite was to

pretend to be intended for use in church, though, notwithstanding its remarkable range of more than 200 songs, its choice of festive occasions is still somewhat random, leaving gaps for some quite major saints. Despite its apparent deficiencies, I argue that it might have served as a songbook for occasional use in the low mass (missa lecta), a Catholic ritual feature which seems to have been introduced in Suprasl prior to 1687, when Metropolitan Kypriian Zhokhovs'kyi (Cyprian Żochowski) praised it as a time-honoured venerable practice of that monastery (Stern, Die Liederhandschrift 301; Stern, "Vidnosyny"). The Uniate monastery at Suprasl even seems to have introduced a Ruthenian-Church Slavonic syllabic translation of the hymn 'Dies irae' into its funeral services as early as the $1630 \mathrm{~s}$ (Stern, "Der kirchenslavische Tag des Zorns"). In the end, however, there are hardly any clear indications which would enable dating with any certainty the establishment of devotional songs as accompanying part of the liturgical practice (Žeňuch, "Paraliturgická pieseň" 67). The earliest source recommending the singing of devotional songs in the context of the missa lecta is the abridged edition of the Bohohlasnyk Pěsni blagogověinyia, vkratcě sobrannyia, published at the monastery of Pochaiv in 1806 (Medvedyk and Rothe 2: 111).

${ }^{23}$ Alternatively, it could, however, be assumed that text and melody were as a rule not closely associated and could be assigned at random and even spontaneously. As a parallel case, one can cite the assignment practice of melodies in song collections of the Devotio moderna (van der Poel and de Morrée 378). Any new song could be assigned to an existing well-known melody which happened to fit its metric structure and composition. 
be preserved unscathed by any Catholic innovations. ${ }^{24}$ This looks very much as though it was the private love and appreciation for these particular songs, which in the long run made them part of the official liturgical practice, at least of the Uniate Church. Privately collecting songs would thus qualify as a major precondition for their introduction into church services and should, accordingly, predate it. The production of manuscript collections of devotional songs is therefore unlikely to have been set going by any kind of change of church regulations, which, as a rule, hardly ever addressed minor issues such as the singing of devotional songs, anyway. ${ }^{25}$ Thus, devotional songs were probably never more than a much appreciated addition to the church service. The traditional Byzantine-Slavic hymnography remained in power as the true, statutory, and constitutive musical foundation of the Uniate church service. The only required book for a parish cantor would therefore be a hirmologion or trebnik, such as Ioann Bokshai's 1906 edition of the Tserkovnoe prostopenie (Church Monodic Chant) for the Eparchy of Mukachevo. ${ }^{26}$

24 Pope Urbanus VIII decreed in 1624 that no Greek Catholic was allowed to swap rites and that no changes be applied to the Byzantine rite (Madey 48). This decree was officially reaffirmed by the Papal See in 1731, due to growing Latinizing tendencies, possibly in the wake of the Synod of Zamostia (Madey 88).

${ }^{25}$ During the period in question, major changes in liturgical practice and church organization within the Uniate Church were indeed instigated by the Synod of Zamostia of 1720 . This synod is said to have essentially promoted the Latinization of the Byzantine rite, though on closer scrutiny it appears to have been much more conservative and protective of the Byzantine rite than often reported (Madey 78-84). It cannot be excluded that the reforms mandated by this synod might have inspired parish priests to include devotional songs in their church services, but the synodal document itself (Synod prowincialny ruski w Mieście Zamoyściu Roku 1720 odprawiony) does not address matters of singing and songs as part or accompaniment of divine services. At best, this synod provided the framework within which parish priests could feel free to introduce changes which were hitherto deemed forbidden. The overall official conservatism of Greek Catholic liturgical practice can still be gleaned from liturgical books from as late as the mid-19th century, such as Iakov Th. Golovatskii's Чинъ сващенныа и божественныа лїтургїи бываемыл сице въ гр. каө. церкви (Lviv, Stavropigiiskii institute, 1858), which does not indicate the slightest possibility of inserting devotional songs at any point.

${ }^{26}$ As Steshko vividly remembers from his field trip to Transcarpathia, the required hymnbook (by Ioann Bokshai) was in fact present at the parishes he visited, but was largely ignored when it came to the actual singing. Both the cantor and the parish, instead of sticking to the hymns and melodies as described by the book, sang from memory in a style which bore hardly any resemblance to Bokshai's musical scores. So, in the end, even the required professional books turn out to have been largely redundant in real life church practice. 
When dealing with devotional songs, another group of professionals comes to mind, namely, the blind minstrels (Russ., kaliki perekhozhie; Ukr., lirnyky) (Kononenko; Kushpet). Since they were blind, written repertoires would have been of little use to them, and in fact this famous class of people relied exclusively on their memory for their repertoire. This might in principle also have been true of their seventeenth-eighteenth century historical predecessors, the wandering seminarians (mandrivni diaky), who, during their vacations, would roam the countryside and earn a subsistence living just like the kaliki/lirnyky by singing songs on various occasions (annual fairs, church holidays, etc.). If these restricted their repertoire to a mnemotechnically manageable number of different items, there would be no need for them to be equipped with a songbook. There are, however, a number of songbooks whose casual makeup, random order, and small pocket size are suggestive of their having been taken on the road. The question remains whether they were taken on the road in order to acquire new songs while travelling or serve as a means of subsistence for travelling seminarians, or whether they were just taken along as edifying reading material while on the road.

For Peretts there is little doubt about the motives behind compiling and owning song collections. No matter what professional class a manuscript owner belonged to, he considers them all alike as lovers and connoisseurs (liubiteli) of this particular kind of poetry, ${ }^{27}$ which is perfectly in line with the title of Iakov Dobrynin's song collection, printed in 1799 in Moscow at Dobrynin's own cost for the benefit of lovers of devotional and festive songs (Духовные и торжественные псальмы, собранные в пользу любителей оныхъ Московскимъ купцомъ Яковомъ Добрынинымъ) (Peretts 305). Clerks, merchants, army officers, and individuals in many other walks of life were owners of song collections that could not be put to any professional use apart from being sold, suggesting that songs were collected for private leisure.

A characteristic that must not be ignored in evaluating the professional usefulness and employability of song collections is that although exclusively devotional collections predominate, mixed collections are prominent among all professional classes. These either contain a small number of secular songs (mostly panegyric, sometimes lyrical love songs, some of which-as in LNBS Petrushevych 135-were even of a frivolous nature, and very few historical songs) or show an equal number of both genres, separated by adjoining

\footnotetext{
${ }^{27}$ In much the same vein, Findeizen stresses private ownership by amateurs as a basic trait of all manuscripts, at least in Russia (2: 133-34). Likewise, Pozdneev views the appearance of devotional songs in late seventeenth-century Moscow and its surroundings as a manifestation of the growing desire for the intimacy of individual spirituality (17).
} 
subsections. There is no clear bias among secular professions for mixed collections, or for exclusively devotional collections among parish priests and cantors. This finding obliquely corroborates the assumption that personal taste rather than professional needs determined the overall makeup of collections.

In the end, the question remains what those lovers of devotional songs did with their collections, once they were completed. Did they really sing these songs on certain solemn social occasions or let others sing from them? ${ }^{28}$ If this was the case though, the song collection would clearly form part of the private sphere of leisure, and its ultimate role would be functional rather than being a coveted object in and of itself. Or were the collections just owned and placed on a shelf for the occasional visitor to admire while leafing through them, or perhaps every once in a while to be taken down from the shelf during one's moments of leisure? This would point to their being acquired as status symbols, reminiscent of modern-day consumerism. Or were these songs perhaps read silently in private moments rather than sung out loud among a company of visitors and friends? This particularly intimate relationship with the final product of one's labours would certainly best align with the likewise utterly personal endeavour of going about to collect songs in a private quest over the years. Likely, it was a combination of all three elements, though singing would, given the general lack of musical scores in many if not most Ruthenian and later Russian manuscripts, hardly be practicable. As for enjoying the songs as such by reading them in private moments, there is at least one direct testimony from an eighteenth-century Russian mixed devotional-secular song manuscript (RGB Undol'skii 1341), which has the following note in Polish on fol. 62r: "I read this book and found many interesting things, nobleman of the Crimean infantry regiment and closest relative of Praskowia, Grigoriy Sargutowicz" (Peretts 301-02). ${ }^{29}$ This individual statement is put into the perspective of a much broader, widespread phenomenon by the preface to the Pochaiv Bohohlasnyk of 1790, whose editors justify their having composed the music for most songs by themselves, because they could not identify the songs' melodies from the extant manuscript sources, concluding that these songs were read rather

\footnotetext{
${ }^{28}$ Which occasions these might be is largely a matter of conjecture, with the possible exception of pilgrimages to miraculous icons of the Virgin Mary or to one of the numerous calvaries which mushroomed throughout the Polish-Lithuanian Commonwealth from the 17 th century onwards. Almost all of the richer and more neatly structured collections of devotional songs reserved a separate section for songs in honor of various miraculous icons (Medvedyk, "Ukrains'ki bohorodychni kanty").

29 "Czitałem tę książkę y znalazłem wiele czekawosci, krymskiego pułku piechoty dworanin i naybłiższy rodacz Praskowiy Grigoriy Sargutowicz.”
} 
than sung (Medvedyk and Rothe 3; vol. I). ${ }^{30}$ Though, generally speaking, Ruthenian authors and compilers of anthologies of religious poetry made an effort to keep songs (pesni) and poetry (virshy) separate, there is at least one notable exception to this (Stern, Die Liederhandschrift 333). In his foreword to Perlo mnogotsennoe (Most Precious Pearl, Chernihiv 1646), Kyrylo Trankvilion Stavrovets'kyi suggests that his poems may either be sung or read as a means of private devotion: "And if someone desires the Mother of God as his patroness, he should read and sing her praise every Saturday, then he will soon feel an improvement of his life" (Trunte I, 11; II, 197). ${ }^{31}$ These findings put the debate about the dividing line between songs and poetry that I introduced earlier, into a new perspective (Die Liederhandschrift 33035). I based my argument in favour of a fairly strict genre division between songs and poetry on the fact that both are seldomly ever conflated in the same manuscripts, assuming, in contrast to Drage (69-70), that it was singability that made the difference. It may still hold that the portentous virshy, published in respectable print editions, were never meant to be sung and were probably not considered singable by anyone (with the exception of Stavrovets'kyi). As for the religious songs, which were mostly transmitted in manuscripts, singability should, however, be considered a preferred rather than a prescribed mode of execution, which on the face of it appears to weaken the strength of singability as a defining feature. Ultimately, singability may still prove a viable criterion, if it is not taken in a strictly technical sense, but rather in a broader meaning encompassing general notions of style and taste, which would exclude erudite, too heavily philosophical and theological, or too obviously educative poetry from being considered appropriate song material by most song lovers.

\section{CONCLUSION}

Do the collecting habits which evolved around devotional songs throughout eighteenth-century Ruthenian and Russian territories testify to the emergence of industrial age patterns of individualistic, class-bound consumerist behaviour? Are devotional songs turned by any means into commodities? There is little evidence indeed that professional production and trade chains for song collectors evolved, as they did, for example, for

\footnotetext{
30 “убо и тыя къ прочтенїю токмш, не къ пънїю послужиша." These observations are in line with what Matija Ogrin hypothesized with respect to seventeentheighteenth century privately owned Slovenian song manuscripts.

31 “А если бы теж хто схотьлъ мъти собъ за патрону мтүръ бӝїю, нехайже похвалу ей читает' и спЊваєт на кождую суботу, прудко таковый почует поправу живота своегш."
} 
stamp collecting. There is not even evidence that songs were sold piecemeal, though whole song manuscripts were indeed sold. There are, however, some indications that collecting songs became emblematic of belonging to the rising literate middle classes. Perhaps collecting or at least owning songs was even considered a matter of propriety within these same classes. This would be in line with Bourdieu's idea of distinctions serving to build up social capital within one's social group. As with so many forms of the accumulation of social capital, in song collecting, behavioural patterns (collecting) combine with symbolically laden material objects (devotional songs) to delimit social boundaries and at the same time allow the individual to pledge social allegiance in terms of the group's economy of meaning. The individual endeavour encapsulated in the act of collecting itself turns class affiliation into a fluid process of negotiation rather than a predetermined status. This is made evident in the attempts of a few artisans and peasants who sought to lay claim to middle class respectability by embracing the middle-class habit of compiling or acquiring collections of devotional songs. What indeed feels the most modern about the compilation of private, individualized collections of songs is the solitude and intimacy of the collecting activity itself. It is true that devotional songs were collected in a very similar manner much earlier, starting from the fourteenth century onward. The framework in which the collecting activity was embedded back then, though, was the devotio moderna, a movement which happened to introduce into European culture solitary individual contemplation and endeavour as a key feature of modernity. 


\section{Works Cited}

Bourdieu, Pierre. Die feinen Unterschiede. Suhrkamp, 1987.

Dolskaya-Ackerley, Olga. The Early Kant in Seventeenth-Century Russian Music. 1983. University of Kansas, PhD dissertation.

Drage, Charles Lovell. Russian Literature in the 18th Century. C. L. Drage, 1978.

Eremin, Igor' Petrovich, editor. Ivan Vishenskii: Sochineniia. Izdatel'stvo AN SSSR, 1955.

Filosofova, Tatjana. Geistliche Lider der Altgläubigen in Russland. Böhlau, 2010.

Findeizen, Nikolai. History of Music in Russia from Antiquity to 1800. Vol. 2: The Eighteenth Century, Indiana UP, 2008.

Frick, David. Kith, Kin, \& Neighbors: Communities \& Confessions in Seventeenth-Century Wilno. Cornell UP, 2013.

Iavorskii, Iulian. Materialy dlia istorii starinnoi pesennoi literatury v podkarpatskoi Rusi. Orbis, 1934.

Ivchenko, Larysa Vasylivna, and Volodymir I. Krekoten', editors. Ukrains'kyi kant XVIIXVIII stolit'. Muzychna Ukraina, 1990.

Jensen, Claudia R. Musical Cultures in Seventeenth-Century Russia. Indiana UP, 2009.

Kononenko, Natalie. Ukrainian Minstrels: And the Blind Shall Sing. M. E. Sharpe, 1998.

Kostiukovets, Larisa F. Kantovaia kul'tura v Belorussii. Vysshaia shkola, 1975.

Kushpet, Volodymyr. Startsivstvo: mandrivni spivtsi-muzykanty v Ukraini (XIX-poch. XX st.). Tempora, 2007.

Kuz'mins'kyi, I. Iu., and M. M. Kapral'. “Spiv u L'vivs'kii Bohoiavlens'kii tserkvi (vid vytokiv do kintsia XVIII stolittia)." Naukovyi visnyk natsional'noi muzychnoi Akademii Ukrainy im. P. I. Chaikovs'koho, no. 121, 2018, pp. 101-08.

Livanova, Tamara Nikolaevna. Russkaia muzykal'naia kul'tura XVIII veka v ee sviaziakh s literaturoi, teatrom i bytom. Vol. 1, Gosudarstvennoe muzykal'noe izdatel'stvo, 1952.

Madey, Johannes. Kirche zwischen Ost und West. Beiträge zur Geschichte der Ukrainischen und Weißruthenischen Kirche. Ukrainische Freie Universität, 1969.

Makhnovets', Leonid Ie. Istoriia ukrains'koi literatury. Vol. 1, Derzhavne vydavnytstvo khudozhn'oi literatury, 1967.

Martynenko, Dar'ia. "Hryhorii Skovoroda ta instytut mandrivnoho vchytel'stva." Pereiaslavs'ki Skovorodynivs'ki studii, no. 1, 2011, pp. 293-98.

Medvedyk, Iurii Ievhenovych. "Rukopysnyi zbirnyk dukhovnykh pisen': shliakh vid ukladacha do doslidnyka (sotsial'nyi status perepysuvacha, naukovo-poshukova misiia kolektsionera)." Ad fontes. Z istorii ukrains'koi muzyky XVIII-pochatku XX st., LNU im. Ivana Franka, 2015, pp. 94-105.

---. "Ukrains'ki bohorodychni kanty druhoi polovyny XVII-XVIII st." Narodna tvorchist' ta etnohrafiia, no. 269, 1999, pp. 71-80.

Medvedyk, Iurii Ievhenovych, and Hans Rothe, editors. Bogoglasnik. Pěsni blagogovějnyja (1790/91). Ein Sammlung geistlicher Lieder aus der Ukraine. Böhlau, 2016. 2 vols.

Neumann, Vladimir. Polnische Kirchenlieder in Moskau am Ende des 17. Jahrhunderts. Kommentierte Textedition der Liederhandschrift Pogodin Nr. 1974 aus der Russischen Nationalbibliothek. Böhlau, 2016. 
Ogrin, Matija. "Early Modern Slovenian Manuscripts and Methods of Digital Humanities." SEELECTS 2017-18, 17 May 2018, Department for East European Languages and Cultures, University of Ghent. Public lecture.

Peretts, Vladimir N. Istoriko-literaturnye issledovaniia i materialy. Bd. I/1, F. Vaisberg and G. Gershunin, 1900.

Petty, Antje. "'Dies schrieb Dir zur Erinnerung ...' from Album Amicorum to Autograph Book." Max Kade Institute Friends Newsletter, no. 16, 2007, pp. 1-8.

Pidłypczak-Majerowicz, M. Bazylianie $w$ Koronie $i$ na Litwie. Szkoły i książki $w$ działalności zakonu. Państwowe wydawnictwo naukowe, 1986.

Pikhura, Guy. "The Podobny Texts and Chants of the Supraśl Irmologion of 1601." The Journal of Byelorussian Studies, vol. 2, no. 2, 1970, pp. 192-221. DOI: 10.30965/20526512-00202003

Plotnikova, Natal'ia Iur'evna. "Pevcheskie tsentry Rossii XVIII veka (po materialam partesnykh rukopisei GIM)." Vestnik PSTGU, II: Muzykal'noe iskusstvo khristianskogo mira, nos. 1-2, 2008, pp. 31-43.

Pozdneev, Aleksandr Vladimirovich. Rukopisnye pesenniki XVII-XVIII vv. Iz istorii pesennoi sillabicheskoi poezii. Nauka, 1996.

Rabus, Achim. Die Sprache ostslavischer geistlicher Gesänge im kulturellen Kontext. Weiher, 2008.

Rothe, Hans. "Eine 'polnische' Liederhandschrift in Moskau." Beiträge zur slawischen Philologie. Festschrift für Fred Otten, edited by Wolfgang Gladrow and Dieter Stern, Peter Lang, 2007, pp. 83-95.

Sidorenko, Halyna Kindrativna. Zarys wersyfikacjij ukraińskiej. Ossolineum, 1961.

Speranskii, Mikhail N. Rukopisnye sborniki XVIII veka. Izd. AN SSSR, 1963.

Stern, Dieter (Stern, Dieter Hubert). "Der kirchenslavische Tag des Zorns.” Uslyshat' os' zemnuiu. Festschrift for Thomas Langerak, edited by Ben Dhooge and Michel De Dobbeleer, Pegasus, 2016, pp. 537-69.

---. Die Liederhandschrift F 19-233 (15) der Bibliothek der Litauischen Akademie der Wissenschaften. Böhlau, 2000.

---. "Dukhovnyi kant-vozmozhnosti i granitsy ego genealogicheskoi rekonstruktsii." Russica Romana, no. 8, 2001, pp. 231-37.

---. "Vidnosyny dukhovnykh pisen' do liturhii u skhidnykh slov"ian v XVII-XVIII stst." Slovensko-rusínsko-ukrajinské vzt'ahy od obrodenia po súčasnost', edited by Ján Dorul'a, Slavistický kabinet SAV, 2000, pp. 321-30.

Steshko, Fedir. "Tserkovna muzyka na Pidkarpats'kii Rusi." Naukovyi zbirnyk tovarystva "Prosvita" v Uzhhorodi, no. 12, 1937, pp. 118-28.

Stryps'kyi, Hiiador. Starsha rus'ka pys'mennist' na Uhorshchyni. Ungvar, 1907.

Tichý, František. Česko-slovenské písně v moskevském spěvníku. Nákl. Učené společnosti Šafař́ḱkovy v Bratislavě, 1931.

Trunte, Hartmut. Cyrillus Tranquillus Stavroveckij, 'Perlo mnohocěnnoje.' Böhlau, 1984-85. 2 vols.

van der Poel, Dieuwke, and Cécile de Morrée. "Authorial and Editorial Roles in Song Manuscripts of the Devotio Moderna." The Dynamics of the Medieval Manuscript, edited by Karen Pratt et al., V\&R unipress, 2017, pp. 367-88.

Vodoff, Wladimir. "Les recueils manuscrits de vers religieux chez les Slaves de rite oriental au XVIII et au début du XIXe siècle." Revue des études slaves, no. 49, 1973, pp. 359-72. 
Vozniak, Mykhailo. Istoriia ukrains'koi literatury. Vol. 3, pt. 2., Prosvita, 1924.

Zatyliuk, Iaroslav V. "Z istorii rozvytku kul'tu Kyievo-Brats'koi Bohorodytsi: 'Pisnia Kyivs'ka 1690-kh rokiv ta ii dzhereloznavchyi potentsial.” Naukovyi visnyk natsional'noho muzeiu istorii Ukrainy, no. 4, 2018, pp. 264-76.

Žeňuch, Peter. Kyrillische paraliturgische Lieder. Edition des handschriftlichen Liedguts im ehemaligen Bistum Mukačevo im 18. und 19. Jahrhundert. Böhlau, 2006.

---. “Paraliturgická pieseň východného obradu." Slovanské štúdie, no. 2, 1994, pp. 6686.

Zhitetskii, P. I. "Stranstvuiushchie shkol'niki v starinnoi Malorossii." Kievskaia starina, no. 36, 1892, pp. 189-205.

Zosim, Ol'ha. Skhidnoslov"ians'ka dukhovna pisnia: sakral'nyi vymir. Derzhavna akademiia kerivnykh kadriv kul'tury i mystetstv, 2017.

---. Zakhidnoievropeis'ka dukhovna pisnia na skhidnoslov"ians'kykh zemliakh u XVII-XIX stolittiakh. Derzhavna akademiia kerivnykh kadriv kul'tury i mystetstv, 2009.

\section{List of Manuscript Repositories}

GIM - Gosudarstvennyi istoricheskii muzei, Moscow

IL - Instytut literatury im. Shevchenka AN Ukrainy, Kyiv

LNBS - L'vivs'ka naukova biblioteka im. Stefanyka AN Ukrainy, Lviv

LRMA — Lietuvos Respublikos Mokslu Akdemijos Centrine Biblioteka, Vilnius

MGU - Moskovskii gosudarstvennyi universitet, Moscow

NBU - Naukova biblioteka im. Vernads'koho AN Ukrainy, Kyiv

NMASh — Natsional'nyi muzei im. Andreia Sheptyts'koho, Lviv

NKP — Národní knihovna České republiky, Prague

RGADA - Rossiiskii gosudarstvennyi arkhiv drevnikh aktov, Moscow

RGB - Rossiisskaia gosudarstvennaia biblioteka, Moscow

RNB - Rossiiskaia narodnaia biblioteka, Moscow

TM - Tverskoi gosudarstvennyi ob"edinennyi muzei, Tver 